Bangladesh J. Bot. 43(3): 249-253, 2014 (December)

\title{
POLLINIA MORPHOLOGY TO SOME MEMBERS OF ASCLEPIADACEAE OF PAKISTAN
}

\author{
Shumaila Yaseen and Anjum Perveen* \\ Department of Botany, University of Karachi, Karachi-75270, Pakistan
}

Key words: Pollinia morphology, Asclepiadaceae

\begin{abstract}
Diversities in the pollinia morphology of the family Asclepiadaceae in respect to pollinium shape, size, color, length and breadth of pollinial sac, length and breadth of corpusculum and length and breadth of caudicle were studied in 13 species belonging to eight genera (Cynanchum L., Calotropis R.Br., Glossonema Decaisne., Leptadenia R.Br., Pergularia L., Sarcostemma R.Br., Tylophora R.Br and Vincetoxicum N. M. von Wolf.) Calotropis procera (Ait.) Ait. f. yielded largest pollinia sac. (906.4 4.4.7 $\mu \mathrm{m}$ ) whilst the smaller one $(109.8 \times 48.0 \mu \mathrm{m})$ was represented by Cynanchum pollens Hemsley and Lace. In respect of the length and breadth of the corspuseulem, C. Procera yielded the lowest one bt Leptodaenia pyrotechnium yielded the smallest $(65.2 \times 41.2 \mu \mathrm{m})$.
\end{abstract}

\section{Introduction}

Asclepiadaceae is a large family of nearly 248 genera and 2800 species widely distributed in the tropical and warm tropical regions and a few of them in temperate regions (Mabberely 1987). In Pakistan, it is represented by 23 genera and 41 species (Ali 1983). The infra-familial classification of Asclepiadaceae was proposed by (Brown 1810). In the present account, Asclepiadaceae is treated as a family according to (Schumann 1895, Bruyns and Froster 1991 and Liede and Albers 1994). Here it is subdivided into 3 subfamilies, 1. Asclepiadoideae, 2. Periplocoideae and 3. Secamonoideae. The family is characterized by having bisexual flowers with gamopetalous corolla, calyx united, shortly connate or almost free. Stamens 5, epipetalous. 5corona present facing towards the center of the flower. Ovary superior, bicarpllary, fruit follicles.

Pollen morphology of Asclepiadaceae is different from the pollen morphology of other families, due to the presence of pollen grains that form hard sac-like definite structure called pollinium. Asclepiadaceae is composed of 2 or more pollinia, in which all the pollen grains of a single anther locule are embedded in a hard structure and a translator attachment, which develops from a stigmatic secretion and mechanically attach the pollinia to a pollinator (Corry 1883, Schill and Jakel 1978, Kunze 1993 and Swarupannandan et al. 1996). Pollinial wall is acetolysis resistant (Erdtman 1952, Nambooderi and Sreedevi 1980). Pollinial wall is made of amorphous sporopollenin enclosing the pollen mass each with a lamellate exine (Sinha and Mondal 2011). There is a lot of work found in pollination ecology of Asclepiadaceae. The observation of pollination in Sarcostemma has been investigated by (Kunze and Liede 1991). There are some reports on pollination ecology of some members of Asclepiadaceae from Pakistan (Ali 1994). There are some reports on pollinia morphology of the family Asclepiadaceae from West Bengal, India (Sinha and Mondal 2011). The Present investigation is based on the pollinia morphology of 13 species representing 8 genera of the family Asclepiadaceae by light Microscope not previously reported from Pakistan hence it is considered as new contribution to the family.

*Author for correspondence: Centre for Plant Conservation, University of Karachi, Karachi-75270, Pakistan. $<$ Anjum_tahir@hotmail.com>. 


\section{Materials and Methods}

The samples of pollinia were obtained from 13 species of Asclepidiaceae preserved in the Karachi University Herbarium and Center for Plant Conservation. For light microscopy the slides were prepared by mounting the pollinia in unstained jelly and observed under a Nikon Type-2 microscope. For each taxon 3 - 5 replicate samples were studied and the measurements were recorded.

The photomicrographs of pollinia were taken by using the Flourescent Electron Microscope (BX-51 Olympus, Japan).

The pollinia morphology of 13 species Cynanchum actum L., Cynanchum dalhousia Wight, Cynanchum petrens Hemsley \& Lace, Calotropis procera (Ait.) Ait. f., Glossonema variens (Stock) Hook. f., Leptadenia pyrotechnica (Forssk.) Dene, Pergularia daemia (Forssk.) Chiov., Pergularia tomentosa L., Sarcostemma viminale (L.) R. Br. Stocki, Sarcostemma viminale subsp.viminale, Tylophora indica (Brum, f.) Merr., Tylophora hirsuta (Wall) Wight. and Vincetoxicum stocksii Ali \& S. Khatoon). representing 8 (Cynanchum L. Calotropis R. Br., Glossonema Dacaisne, Leptadenia, Pergularia L. Sarcostemma R. Br., Tylophora R. Br. and Vincitoxicum N. M. von Wof.) genera of the family Asclepiadaceae are described on the basis of their shape, size, length and breadth of pollinial sac, length and breadth of caudicle, length and breadth of corpusculum and the data are presented in Table 1. Photomicrographs of the pollinia have been presented in Fig. 1a-n.

\section{Results and Discussion}

The family Asclepiadaceae is commonly known as Milkweed family and is unique due to the presence of Pollinia. According to Sinha and Mondal (2011), the species of the family Asclepiadaceae differ remarkably depending on Pollinia. Present study also confirms it. The infrafamilial classification of Asclepiadaceae was proposed by Brown (1810b). Asclepiadaceae treated as a family, divided into three subfamilies by Schumann (1895), Bruyns and Froster (1991), Liede and Albers (1994). In the present study, the largest pollinial sac is found in the species Calotropis procera. In the genus Cynanchum three species namely, Cynanchum actum, C. dalhousia and C. petrens having pollinia of canary yellow color and basally inserted on the corpusculum. In the genus Calotropis, Glossonema, Leptadenia and Vincetoxicum characters are same as those of species. In all the species, orientation of pollinia is pendulous except in Leptadenia and Tylophora. In Pergularia, pollinia possessed laterally compressed corpusculum but caudicle is absent. Pollinial sac is directly attached to corpusculum. Pollinia are subsessile, flattened and lanceolate. In the subsp. of Sarcostemma, caudicle is basally attached to the corpusculum. In Tylophora, corpusculum is obovate in shape. Caudicle is slightly curved and basally attached to the corpusculum In Tylophora sp. pollinia are apically attached to the caudicle (Sinha and Mondal 2011). The pollinia belonging to different genera and species of Asclepiadaceae is provided below. Since a single species was studied in each of calotropis, Glossonema, Leptodenia an Vincetoxicum, the size range of pollinial characteristics are similar to those described for the speices (Table 1).

Cynanchum: Pollinial sac 109.8 - $415.4 \mu \mathrm{m}$ long and 48.0 - $133.9 \mu \mathrm{m}$ broad, caudiale 92.7 $103 \mu \mathrm{m}$ long and 30.7 - $82.4 \mu \mathrm{m}$ broad, corpusculum 164.8 - $295.2 \mu \mathrm{m}$ long and $61.8-144.2 \mu \mathrm{m}$ broad (Table 1). Morphological variation recorded for different speciss under this genus is given below.

Cynanchum actum: Pollinial sac canary yellow, pollinium laterally attached to the caudicle, basally inserted on the corpusculum, corpusculum oblong and pollinium is oval in shape (Fig. 1a). 
Cynanchum dalhousia: Pollinia sac is canary yellow, orientation of pollinium is pendulous, laterally attached to the caudicle, corpusculum and pollinial sac is oval (Fig. 1b).

Cynanchum petrens: Pollinial sac canary yellow, orientation of pollinium pendulous, pollinia laterally attached to the caudicles, corpusculum oblong, pollinial sac oval.

Calotropis procera: Pollinia canary yellow, orientation pollinium is pendulous, ellipsoid and lacking a pellicid germinating mouth, corpusculum and pollinial sac is obovate (Fig. 1d, e).

Table 1. Sizes of pollinia of different taxa of family Asclepiadaceae found under the investigation.

\begin{tabular}{lcccccc}
\hline $\begin{array}{l}\text { Name of } \\
\text { species }\end{array}$ & $\begin{array}{c}\text { Length of } \\
\text { pollinial sac } \\
(\mu \mathrm{m})\end{array}$ & $\begin{array}{c}\text { Breadth of } \\
\text { pollinial sac } \\
(\mu \mathrm{m})\end{array}$ & $\begin{array}{c}\text { Length of } \\
\text { caudicle } \\
(\mu \mathrm{m})\end{array}$ & $\begin{array}{c}\text { Breadth of } \\
\text { caudicle } \\
(\mu \mathrm{m})\end{array}$ & $\begin{array}{c}\text { Length of } \\
\text { corpusculum } \\
(\mu \mathrm{m})\end{array}$ & $\begin{array}{c}\text { Breadth of } \\
\text { corpusculum } \\
(\mu \mathrm{m})\end{array}$ \\
\hline Cynanchum actum & 291.8 & 133.4 & 103 & 68.6 & 240.3 & 133.9 \\
C. dalhousia & 415.4 & 116.7 & 103 & 82.4 & 295.2 & 144.2 \\
C. petrnse & 109.8 & 48.0 & 92.7 & 30.7 & 164.8 & 61.8 \\
Calotropis procera & 906.4 & 504.7 & 298.7 & 44.6 & 351.2 & 113.7 \\
$\begin{array}{l}\text { Glossonema variens } \\
\text { Leptadenia }\end{array}$ & 278.1 & 212.8 & 144.2 & 20.6 & 212.1 & 116.7 \\
pyrotechnica & 175.1 & 144.2 & 103 & 34.3 & 65.2 & 41.2 \\
$\begin{array}{l}\text { P. daemia } \\
\text { P. tomentosa }\end{array}$ & 525.3 & 281.5 & Absent & Absent & 192.2 & 133.9 \\
$\begin{array}{l}\text { Sarcostemma viminale } \\
\text { subsp. stocksii }\end{array}$ & 422.3 & 255.0 & Absent & Absent & 195.7 & 65.2 \\
S. viminale & 295.8 & 60.1 & 110.0 & 20.0 & 135.4 & 85.5 \\
subsp.viminale & 357.0 & 65.2 & 113.3 & 240 & 140.7 & 92.7 \\
$\begin{array}{l}\text { Tylophora indica } \\
\text { T. hirsuta }\end{array}$ & 164.8 & 96.1 & 30.9 & 20.6 & 144.2 & 61.8 \\
Vincetoxicum stocksii & 116.7 & 54.9 & 92.7 & 37.7 & 133.9 & 58.3 \\
\hline
\end{tabular}

Glossonema variens: Pollinia canary yellow, orientation of pollinia pendulous, caudicle basally inserted to the corpusculum, pollinial sac oval and corpusculum oblong (Fig. 1f).

Leptadenia pyrotechnica: Pollinia very small, pollinium canary yellow, orientation of pollinium, corpusculum round, pollinial sac oval (Fig. 1g).

Pergularia: Pollinial sac 422.3 - $525.3 \mu \mathrm{m}$ long and 255.0 - $281.5 \mu \mathrm{m}$ broad, caudicle absent, corpusculum 192.2 - $195.7 \mu \mathrm{m}$ long and 65.2 - $133.9 \mu \mathrm{m}$ broad.

Pergularia daemia: Pollinia with laterally compressed corpusculum, lanceolate, canary yellow in color. Orientation of pollinium is pendulous and mouth is on the outer margin of the pollinium (Bruyns and Forster 1991). Corpusculum ovate (Fig. 1h).

Pergularia tomentosa: Pollinia with translucent outer margin. Pollinia with laterally compressed corpusculum. Pollinia flattened, lanceolate, orientation of polliniun pendulous, mouth on outer margin of the pollinium (Bruyns and Forster 1991). Corpusculum ovate (Fig. 1i).

Sarcostemma: Pollinial sac 295.8 - $357 \mu \mathrm{m}$ long and 60.1 - $65.2 \mu \mathrm{m}$ broad, caudicle 110 - 113.3 $\mu \mathrm{m}$ long and 20 - $24 \mu \mathrm{m}$ in broad, corpusculum 135.4 - $140.7 \mu \mathrm{m}$ long and 85.5 - $92.7 \mu \mathrm{m}$ broad.

Sarcostemma viminale: Pollinia canary yellow, orientation pollinium pendulous, caudicle basally attached to the corpusculum, pollinial sac obovate, corpusculum oval (Fig. 1i). 
Sarcostemma viminale subsp. viminale: Pollinium canary yellow, orientation pollinium is pendulous, corpusculum oval, pollinial sac obovate (Fig. 1k).

Tylophora: Pollinial sac 164.8 - $432.6 \mu \mathrm{m}$ long and 65.2 - $144.2 \mu \mathrm{m}$ broad, caudicle 30.9 $133.9 \mu \mathrm{m}$ long and 20.6 - $72.1 \mu \mathrm{m}$ broad, corpusculum 144.2 - $315.8 \mu \mathrm{m}$ long and $61.8-133.3 \mu \mathrm{m}$ broad (Fig. 1k).

Tylophora indica: Pollinia canary yellow, orientation of pollinium is erect, pollinia apically attached to caudicle, corpusculum obovate in shape, pollinia slightly erect, globular (Fig. 11).
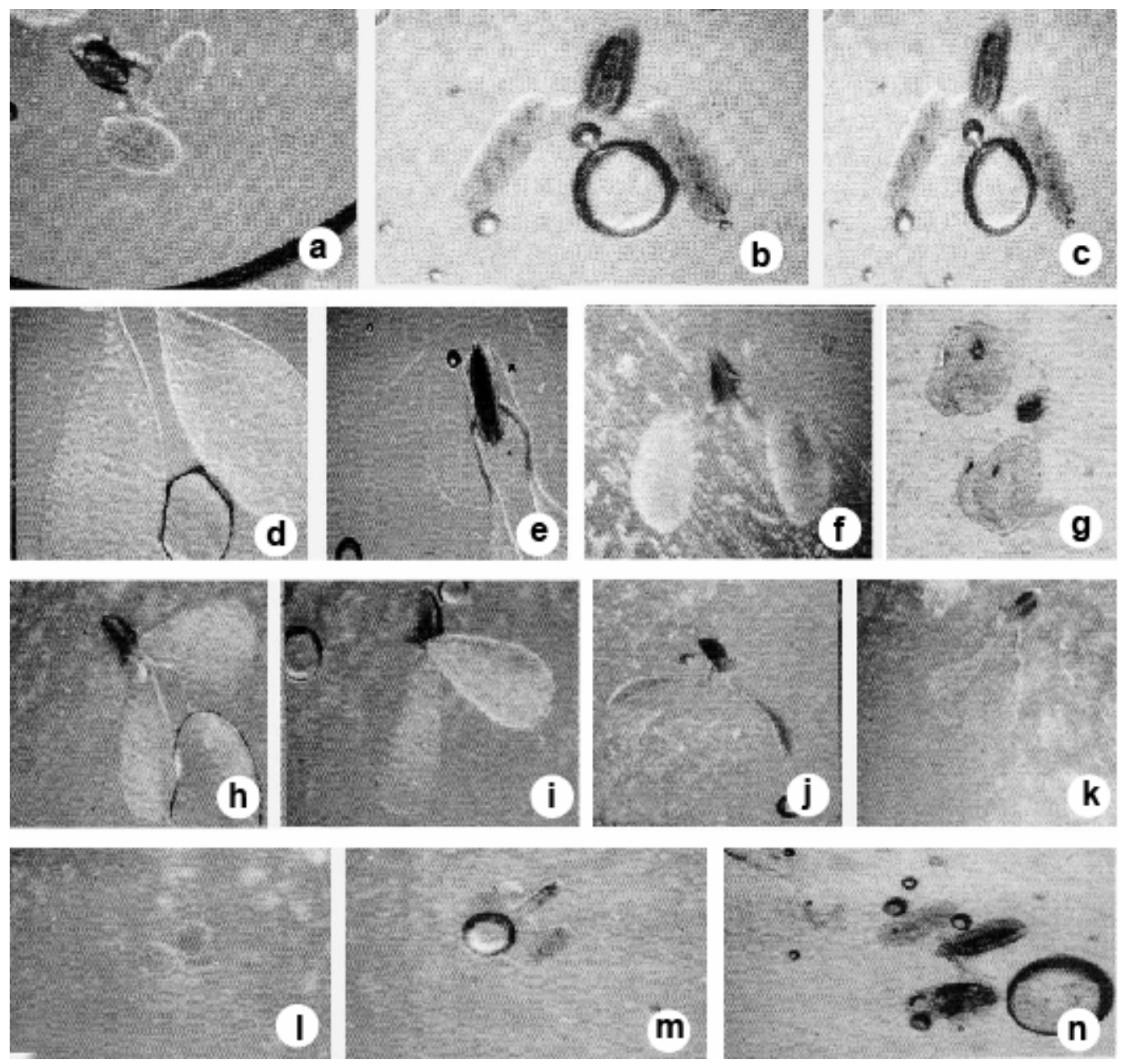

Figs 1a-n. Polinial morphology of different species of Asclepiadaceae. a. Cynanchum actum, b. C. dalhousia, c. petrens, d. Calotrophis procera, e. C. procera, f. Glossonema variens, g. Leptadenia pyrotechnica, h, Pergularia daemia, i. P. tomentosa, j. Sarcostemma viminale, k. Sarcostemma viminale, l. Tylophora indica, m. T. hirsuta, n. Vincetoxicum stocksii.

Tylophora hirsuta: Pollinia canary yellow, orientation of pollinium is erect, corpusculum obovate, pollinia apically attached to caudicle, caudicle slightly curved, basally attached to corpusculum, pollinial sac oval in shape (Fig. 1m). 
Vincetoxicum stocksii: Pollinia canary yollow, color, orientation of pollinium is pendulous, corpusculum ovate, pollinial sac oval (Fig. 1n).

In the present investigation, wide range of variation in respect to size, shape, length and breadth of pollinial sac, length and breadth of caudicle, length and breadth of corpusculum were observed which are in agreement with some previous reports.

\section{References}

Ali SI 1983. Flora of Pakistan, Asclepiadaceae No.150:6-51. Dept. Bot. Univ. Karachi and National herbarium. Pak. Agri. Research. Council , Islamabad.

Ali T 1994. Pollination ecology of some Asclepias from Pakistan. Ph.D Thesis, Univ. Karachi, Pakistan.

Brown R 1810b. On the Asclepiadeae, a natural order of plants separated from the Apocianeae of Jussieu. [Preprint of Mem.Wern.Nat. Hist. Soc. 1: 12-78(1811)].

Bruyns PV and Forster PI 1991. Recircumscription of the Stapetieae (Asclepiadaceae). J. Taxon, 40: 381391.

Corry TH 1883. On the structure and development of the gynostengium, and the mode of fertilization in Asclepias cornuti, Decaisne (A. syriaca L.) Trans. Bot. J. Linn. Soc. London. 2: 173-207.

Erdtman G 1952. Pollen morphology and plant taxonomy. Chronica Botanical C., Waltham, USA.

Kunze H and Liede S 1991. Observations on pollination in Sarcostemma (Asclepiadaceae). J. Pl. Syst. Evol. $178: 95-105$.

Kunze H 1993. Evolution of the translator in Periplocaceae and Asclepiadaceae. J. Plant. Syst. Evol. 185: 99-122.

Liede S and Albers F 1994. Tribal description of genera in the Asclepiadaceae. J. Taxon. 43: 201-231.

Mabberley DI 1987. The Plant Book . Cambridge Univ. Press, Cambridge , New York.

Namboodiri AN and Sreedevi P 1980. Pollen and pollinial wall preparation for cytochemical and anfrared spectroscopic studies: Nature of acetolysis-induced changes. Proceeding of the IV International Palynoligical Conference. Lucknow. 2: 569-573.

Schumann, K. 1895. Apocynaceae and Asclepiadaceae. A Engler \& K Prantt (eds), Nat. Pflanzenfam. 4(2) Engelmann, Leipzig, pp. 109-305.

Schill R and Jakel U 1978. Beitrag zur Kenntnis der Asclepiadaceen Pollinarien. Trop. Subtrop. Pflanzenwelt, 22: 1-122.

Sinha S and Mondal AK 2011. The morphological diversitification of pollinia of some members of Asclepiadaceae. Afri. J. Biotech. 10(41): 7981-7986.

Swarupanandan K, Mangalym Jk, Sonny TK, Kishorekumar K and Vasga SC (Eds) 1996. The subfamilial and tribal classification of the family Asclepiadaceae. Bot. J. Linn. Soc. 120: 327-369. 